TEKNIK, 40 (2), 2019, 99-105

\title{
Analisis Penggunaaan Government Radio Network (GRN) untuk Integrasi Sistem Komunikasi Public Protection and Disaster Relief (PPDR) di Kota Bandung
}

\author{
Tengku Ahmad Riza*), Asep Mulyana, Rendy Munadi \\ Fakultas Ilmu Terapan, Universitas Telkom, \\ Jl. Telekomunikasi No.1, Terusan Buah Batu, Bandung, Indonesia 40257
}

\begin{abstract}
Abstrak
Sistem komunikasi Public Protection and Disaster Relief (PPDR) yang digunakan oleh instansillembaga saat ini tidak terintegrasi. Situasi ini menghambat komunikasi informasi antar instansi/lembaga sehingga memperlambat penanganan bencana. Artikel ini menyajikan penelitian kajian Analisis penggunaan sistem Government Radio Network (GRN) untuk integrasi sistem komunikasi antar instansi/lembaga PPDR. Integrasi ini bertujuan untuk memperlancar aliran informasi antar instansi/lembaga PPDR sehingga mempercepat upaya menangani bencana. Teknologi komunikasi GRN yang digunakan ditentukan dengan melakukan kajian literatur dan studi banding di kota lain di dalam dan di luar negeri. TETRA digunakan untuk simulasi implementasi sistem GRN dalam melayani seluruh kota Bandung dengan frekuensi operasi $400 \mathrm{MHz}$ dan lebar pita $800 \mathrm{KHz}$.
\end{abstract}

Kata kunci: Integrasi; sistem komunikasi; frekuensi; GRN; PPDR; TETRA

\begin{abstract}
[Title: Implementation Analysis of Government Radio Network (GRN) Analysis for Integration of Public Protection and Disaster Relief (PPDR) Communication Systems in Bandung City] Today, PPDR communication system used by agencies/ institutions are not integrated. This situation impedes communication of information between agencies/ institutions thereby slowing down disaster management. This article presents research studies analyzing the use of Government Radio Network (GRN) systems for the integration of communication systems between PPDR agencies/ institutions. This integration aims to facilitate the flow of information between PPDR agencies/ institutions so as to accelerate efforts to deal with disasters. The GRN communication technology used is determined by conducting a literature review and comparative study in other cities in both Indonesia and abroad. TETRA is used to simulate the implementation of the GRN system in serving the entire city of Bandung with an operating frequency of $400 \mathrm{MHz}$ and $800 \mathrm{KHz}$ bandwidth.
\end{abstract}

Keywords: Integration; communication systems; frequency; GRN; PPDR; TETRA

\section{Pendahuluan}

Public Protection and Disaster Relief (PPDR) di Indonesia, merupakan kerjasama banyak instansi seperti BPBD, kepolisian, Search and Rescue (SAR) dan lainlain. Dengan banyaknya instansi yang terlibat, dibutuhkan koordinasi seluruh jaringan komunikasi pihak-pihak yang menangani bencana di Indonesia. Dengan koordinasi komunikasi ini diharapkan

\footnotetext{
${ }^{*}$ Penulis Korespondensi.

E-mail: tengkuriza@ telkomuniversity.ac.id
}

penanganan lebih cepat dan tanggap bila terjadi bencana.

Terkait dengan koordinasi komunikasi untuk PPDR, telah dilakukan beberapa penelitian, diantaranya oleh Yuniarti (2014), yang meneliti bagaimana pemerintah DKI Jakarta melalui beberapa instansi yang terkait PPDR menggunakan teknologi 4G dan beberapa frekuensi sesuai dengan izin yang diberikan oleh regulator. Penelitian alokasi frekuensi PPDR khususnya di daerah Bandung yang dilakukan Manik $d k k$. (2015) menunjukkan bahwa bahwa regulasi frekuensi yang dapat digunakan adalah frekuensi $409-417 \mathrm{MHz}$ dan

doi: 10.14710/teknik.v40n2.21742

Copyright @ 2019, TEKNIK, p-ISSN: 0852-1697, e-ISSN: 240-9919 


\section{Teknik, 40 (2), 2019, 100}

frekuensi 422,5 - 426,6 MHz digunakan untuk komunikasi. Penelitian tentang penggunaan frekuensi juga dilakukan oleh Clara $d k k$. (2016) yang mengkaji Terrestrial Trunked Radio (Tetra) Digital Pada Kereta Bandara Soekarno Hatta - Halim Perdana Kusuma. Dalam kajiannya disebutkan bahwa perencanaan TETRA pada stasiun Soekarno Hatta menggunakan frekuensi 410-420 $\mathrm{MHz}$ dan 420-430 $\mathrm{MHz}$, tidak membahas penggunaan TETRA pada komunikasi layanan PPDR.

Banyaknya instansi/lembaga terkait dengan PPDR yang menggunakan frekuensi dan teknologi perangkat yang berbeda-beda mengakibatkan masalah koordinasi lintas/antar instansi. Ini menjadi latar belakang penelitian tentang Perencanaan Public Protection and Disaster Relief (PPDR) menggunakan Government Radio Network (GRN) dengan studi kasus Di Kota Bandung. Diharapkan hasil kajian ini bisa menjadi masukan untuk integrasi penggunaan teknologi perangkat yang digunakan didalam penanganan bencana oleh instansi terkait PPDR di Indonesia terutama wilayah kota Bandung

\section{Metode Penelitian}

Pada penelitian ini, dilakukan kajian dan analisis Public Protection and Disaster Relief (PPDR) menggunakan metode studi literatur, studi banding, pengolahan dan analisis data. Studi literatur dilakukan untuk mempelajari teori - teori yang dibutuhkan dalam pengerjaan penelitian melalui berbagai referensi baik buku maupun jurnal yang terkait dan juga mempelajari aturan dan implementasi baik Internasional maupun nasional mengenai PPDR. Selain studi literatur juga dilakukan studi banding (benchmark) yang dilakukan dengan membandingkan implementasi kebijakan di berbagai kota di Indonesia maupun di negara lain terkait dengan PPDR. Data yang terkumpul kemudian diolah dan dianalisis untuk melihat kemungkinan dapat diimplementasikan di kota Bandung. Dari analisis ini kemudian disimpulkan teknologi PDDR yang mungkin bisa diimplementasikan di Indonesia, terutama di Kota Bandung.

Penelitian ini dibatasi untuk area operasional berupa seluruh wilayah kotamadya Bandung, sedangkan model prediksi sebagai simulasi menggunaka redaman yang digunakan adalah Model Okumura-Hatta sedangkan layanan PPDR hanya memperhitungkan kejadian operasi harian.

Penelitian ini dilakukan dengan menggunakan pendekatan kuantitatif dan kualitatif serta pembandingkan penggunaan teknologi PPDR yang diterapkan di berbagai kota di Indonesia maupun di negara lain.

\section{Hasil dan Pembahasan}

Dalam mengatasi bencana, tidak ada instansi/Lembaga yang dapat bekerja sendiri, sehingga PPDR ini akan melayani lembaga: (1) Badan Nasional Penanggungan Bencana Daerah (BNPBD); (2) Badan SAR Nasional Daerah (BASARNAS Daerah); (3) Polisi Resort Kota Besar Bandung; (4) Dinas Pemadam Kebakaran Kotamadya Bandung; (5) Satuan Polisi Pamong Praja (Satpol PP) Kotamadya Bandung; (6) Dinas Perhubungan dan Dinas Komunikasi dan Informatika Kotamadya Bandung (SKPD Bandung); dan (7) Palang Merah Indonenesia (PMI) selaku tenaga medis kesehatan. Dengan demikian, penggunaan sistem komunikasi PPDR dikelompokkan menjadi 7 kelompok (talk group) sesuai dengan lembaga PPDR.

\subsection{Kajian Standar dan Pemilihan Teknologi GRN}

Pada awal sistem two-way radio diperkenalkan pada tahun 1940, masing-masing departemen yang menggunakan sistem ini secara sendiri-sendiri dan tidak terintegrasi. Model ini disebut Independent Service Model. Namun pada sekitar tahun 1970 mulai diperkenalkan satu nomor untuk panggilan darurat yang digunakan di Amerika Serikat yaitu no 9-1-1 untuk merespon semua panggilan darurat. Solusi ini membuat respon untuk polisi, ambulan serta pemadam kebakaran menjadi lebih cepat. Model ini yang kemudian dikenal Shared Emergency Dispatch Center Model. Kedua model ini dapat digambarkan pada Gambar 1 (Azmi, 2013).

Di dalam layanan dispatch bersama (Shared Emergency Dispatch Center Model) masih terdapat kekurangan yaitu masing-masing departemen bisa menggunakan frekuensi yang berbeda. Hal ini yang kemudian bisa menimbulkan permasalahan pada sistem komunikasi. Pada perkembangan berikutnya, dalam model GRN dikembangkan penggunakan bersama sistem radio. Model ini disebut Government Radio Network (Small) seperti diperlihatkan pada Gambar 2. Model Government Radio Network (Small) pada Gambar 2 masih merupakan kombinasi antara dispatch center dan emergency call-taking namun sistem radio digunakan dalam satu sistem bersama.

Dilihat dari teknologi terdapat dua jenis komunikasi dua arah untuk digunakan pada komunikasi GRN, yaitu sistem konvensional dan sistem Radio Trunking. Dua kelemahan utama sistem konvensional yaitu rendahnya efisiensi spektrum dan tidak dapat diintegrasikan.

Untuk Teknologi Radio Trunking digital ada yang bersifat open standard dan yang bersifat proprietary, maka pilihan yang tebaik dari keduanya adalah open standard yang mendukung IP. Sistem 


\section{Teknik, 40 (2), 2019, 101}

digital standar internasional yang digunakan di dunia antara lain: (1) Digital Mobile Radio (DMR); (2) Project
25 (P25) dan Terrestial Trunked Radio (TETRA). Tabel 1 memuat perbedaan dari ketiga sistem digital tersebut.

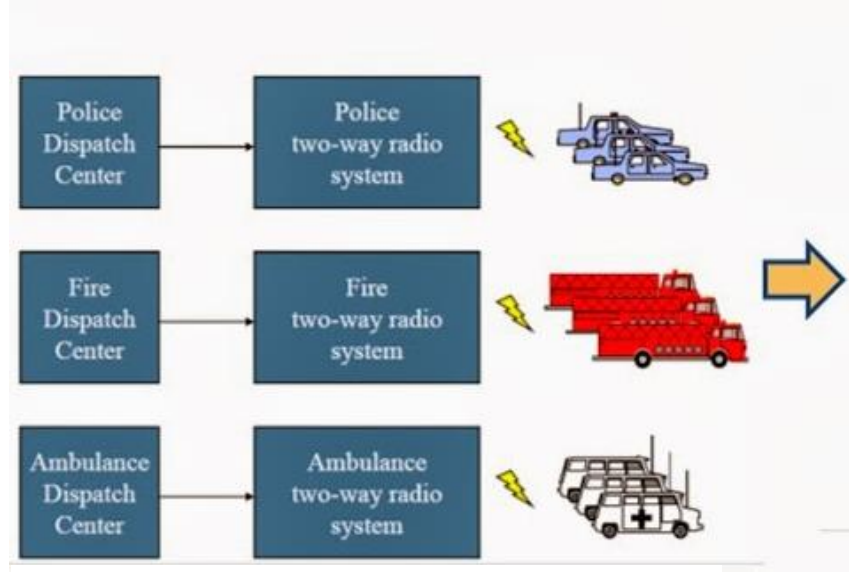

Layanan independen (kota, wilayah propinsi)

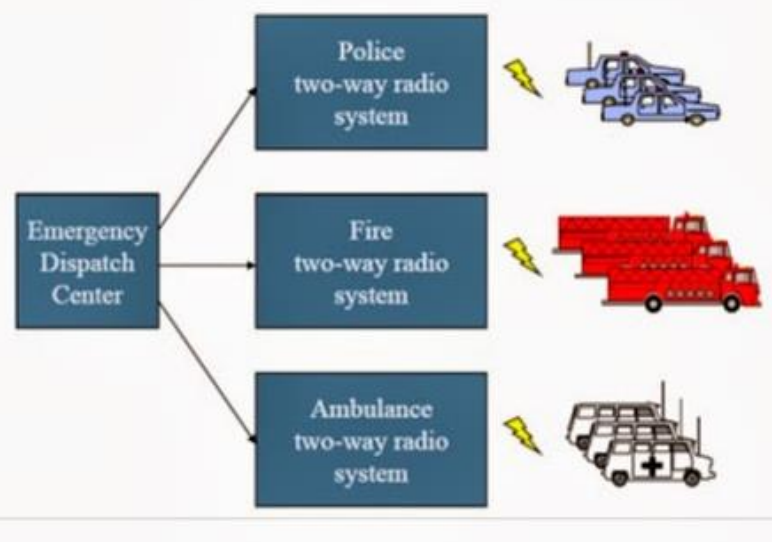

Layanan dispatch bersama

Gambar 1. Model Shared Emergency Dispatch Center.

\section{City or County Government}

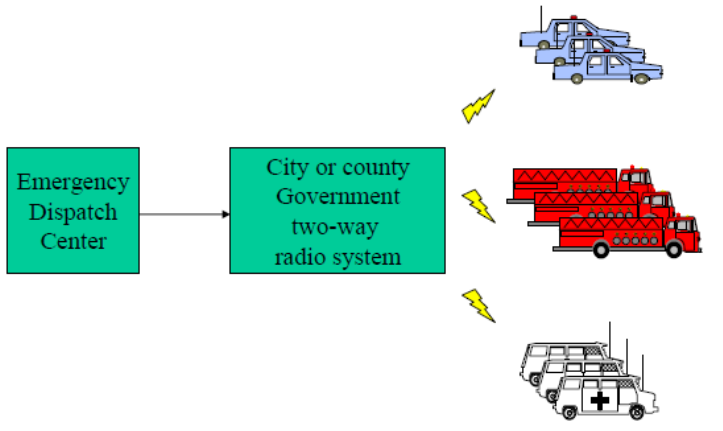

Gambar 2. Model Government Radio Network.

Tabel 1. Perbandingan Sistem GRN Digital.

\begin{tabular}{|c|c|c|c|}
\hline $\begin{array}{c}\text { Faktor } \\
\text { Performansi }\end{array}$ & TETRA & $\begin{array}{c}\text { Project } 25 \\
\text { (P25) }\end{array}$ & DMR \\
\hline Metode Akses & TDMA & $\begin{array}{l}\text { FDMA dan } \\
\text { TDMA } \\
\text { H- }\end{array}$ & TDMA \\
\hline & $\pi / 4$ & DQPSK/H- & \\
\hline $\begin{array}{l}\text { Modulasi } \\
\text { Timeslot per }\end{array}$ & DQPSK & PCM & 4FSK \\
\hline Channel & 4 Slot & $\begin{array}{l}2 \text { Slot } \\
\text { VHF dan }\end{array}$ & $\begin{array}{l}2 \text { Slot } \\
\text { VHF dan }\end{array}$ \\
\hline Frekuensi & $\begin{array}{l}\text { UHF } \\
28.8\end{array}$ & UHF & UHF \\
\hline Data Rate & $\begin{array}{l}\text { kbps } \\
3.8-17.5\end{array}$ & $\begin{array}{l}9.6 \mathrm{kbps} \\
\text { Maksimal } 35\end{array}$ & $\begin{array}{l}9.6 \mathrm{kbps} \\
3.8-17.5\end{array}$ \\
\hline Coverage Area & $\mathrm{km}$ & $\mathrm{km}$ & $\mathrm{km}$ \\
\hline Interoperability & Ya & Ya & Ya \\
\hline Enkripsi & $\mathrm{Ya}$ & $\mathrm{Ya}$ & $\mathrm{Ya}$ \\
\hline
\end{tabular}

TETRA memiliki fitur yang bermanfaat dan berbeda dengan standar DMR dan P23, yaitu call set up cepat sehingga mendukung operasi langsung (direct mode operation) antara dua perangkat, keamanan yang lebih baik dan memiliki effisiensi penggunaan spektrum frekuensi. TETRA dikembangkan untuk dapat digunakan international roaming oleh penyedia jaringan nasional maupun internasional. Perbandingan spektrum efisiensi TETRA ditunjukkan pada Gambar 3 (Nurjihad, S, dkk, 2014).

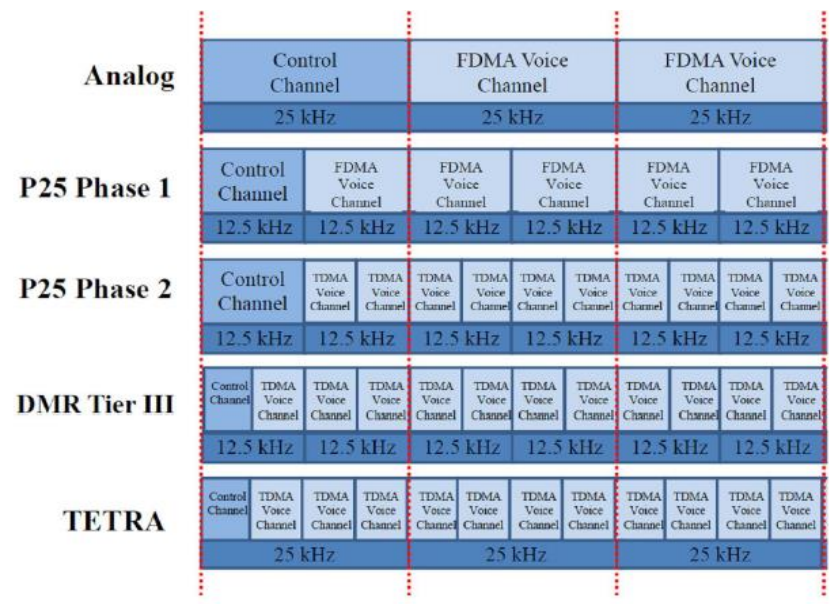

Gambar 3. Perbandingan Spektrum efisiensi (Kunayet, 2014).

Sistem GRN telah digunakan secara luas. Pengguna teknologi digital di internasional yang 


\section{Teknik, 40 (2), 2019, 102}

menggunakan sistem TETRA yang bisa dijadikan sebagai benchmark adalah sistem GRN di (1) Korea Selatan, (2) Malaysia, (3) China, (4) Hongkong, dan (5) Eropa. Penelitian ini mengangkat sistem GRN TETRA karena selain penjelasan sebelumnya, juga TETRA menggunakan standar ETSI sehingga mempermudah interoperabilitas dan didukung banyak vendor.

\subsection{Kajian Simulasi Perencanaan GRN}

Dalam penelitian ini, area penggunaan GRN adalah wilayah Kotamadya Bandung, dimana kota Bandung terletak pada posisi $107^{\circ} 36^{\prime}$ Bujur Timur dan 6055 ' Lintang Selatan dengan luas $\pm 167,3 \mathrm{Km}^{2}$ dengan 26 kecamatan dan 139 kelurahan (Dinas Komunikasi dan Informatika Kota Bandung, 2019). Berdasarkan kondisi topografi, kota Bandung berada pada ketinggian $791 \mathrm{mdpl}$, dimana area tertinggi ada di bagian utara dengan ketinggan $1050 \mathrm{mdpl}$ dan titik terendah berada di bagian selatan dengan ketinggian $675 \mathrm{mdpl}$. Posisi kota Bandung dikelilingi oleh pegunungan sehingga kota ini berada dalam cekungan dan menjadikannya kota rawan bencana.

Berdasarkan kondisi Kota Bandung di atas, penelitian ini menggunakan perangkat yang bekerja pada frekuensi yang digunakan oleh kepolisian (untuk mempermudah komunikasi menggunakan frekuensi yang ada) yaitu pada frekuensi $400 \mathrm{MHz}$ (Aryanta, 2018). dan menggunakan pemodelan propagasi Okumura Hatta karena GRN digunakan pada daerah urban. Model propagasi Okumura Hatta untuk urban terlihat pada Persamaan 1 (Rappaport, 2002).

$\mathrm{Lu} \quad=69.55+26.16 \log (\mathrm{f})-13.82 \log (\mathrm{hb})-\mathrm{a}(\mathrm{hm})+[44.9-$ $6.55 \log (\mathrm{hb})] \log (\mathrm{d})$

Dimana :

$\mathrm{Lu}=$ redaman untuk area urban $(\mathrm{dB})$

$\mathrm{hb}=$ Tinggi antena BS $(\mathrm{m})$

$\mathrm{hm}=$ Tinggi antena MS (m)

$\mathrm{f} \quad=$ Frekuensi $(\mathrm{MHz})$.

$\mathrm{d}=$ Jarak BS - MS (km).

$\mathrm{a}(\mathrm{hm})=$ Faktor koreksi tinggi antena $(\mathrm{dB})$.

MHz:

Untuk kota besar dengan frekuensi di atas 150

$\mathrm{a}(\mathrm{hm})=3.2[\log (11.75 \mathrm{hm})] 2-4.97$

Jika $\mathrm{Lu}$ merupakan nilai maksimum, disebut Maximum Allowable Path Loss (MAPL), maka d yang diperoleh merupakan d maksimum atau Radius (R) dari coverage. Dalam perhitungan radius (R) digunakan analisis power link budget dengan arah dari mobile station (MS) ke Base Transceiver Station (BS), sebagaimana dituliskan pada Tabel 2.
Tabel 2. Perbandingan Spektrum efisiensi (European Telecommunications Standards Institute, 1997)

\begin{tabular}{|c|c|c|c|c|c|}
\hline & $\begin{array}{l}\text { BS to } \\
\text { MS }\end{array}$ & $\begin{array}{l}\text { MS to } \\
\text { BS }\end{array}$ & $\begin{array}{l}\text { BS to } \\
\text { HH }\end{array}$ & $\begin{array}{c}\text { HH to } \\
\text { BS }\end{array}$ & Unit \\
\hline TX power & 44 & 40 & 44 & 30 & $\mathrm{dBm}$ \\
\hline $\begin{array}{l}\text { TX cable and } \\
\text { filter loss }\end{array}$ & 6 & 2 & 6 & 0 & $\mathrm{~dB}$ \\
\hline $\begin{array}{l}\text { TX antenna } \\
\text { gain }\end{array}$ & 8 & 2 & 8 & -4 & $\mathrm{dBi}$ \\
\hline $\begin{array}{l}\text { Peak effective } \\
\text { isotropic } \\
\text { radiated power }\end{array}$ & 46 & 40 & 46 & 26 & $\mathrm{dBm}$ \\
\hline $\begin{array}{l}\text { Propagation } \\
\text { loss }\end{array}$ & $\mathrm{L}$ & $\mathrm{L}$ & $\mathrm{L}$ & $\mathrm{L}$ & $\mathrm{dB}$ \\
\hline $\begin{array}{l}\text { Signal level at } \\
\text { RX antenna }\end{array}$ & $46-\mathrm{L}$ & $40-\mathrm{L}$ & $46-\mathrm{L}$ & $26-\mathrm{L}$ & $\mathrm{dBm}$ \\
\hline $\begin{array}{l}\mathrm{RX} \text { antenna } \\
\text { gain }\end{array}$ & 2 & 8 & -4 & 8 & $\mathrm{~dB}$ \\
\hline RX cable loss & 2 & 4 & 0 & 4 & $\mathrm{~dB}$ \\
\hline $\mathrm{RX}$ input power & $\begin{array}{l}\text { RBS=46- } \\
\mathrm{L}\end{array}$ & $\begin{array}{l}\text { RBS=44- } \\
\text { L }\end{array}$ & $\begin{array}{l}\mathrm{RBS}=42- \\
\mathrm{L}\end{array}$ & $\begin{array}{l}\mathrm{RBS}=30- \\
\mathrm{L}\end{array}$ & $\mathrm{dBm}$ \\
\hline $\begin{array}{l}\text { RX sensitivity } \\
\text { Static } \\
\text { dynamic }\end{array}$ & $\begin{array}{l}-112 \\
-103\end{array}$ & $\begin{array}{l}-115 \\
-106\end{array}$ & $\begin{array}{l}-112 \\
-103\end{array}$ & $\begin{array}{l}-115 \\
-106\end{array}$ & $\begin{array}{l}-\mathrm{dBm} \\
-\mathrm{dBm}\end{array}$ \\
\hline $\begin{array}{l}\text { Maximum } \\
\text { acceptable } \\
\text { median path } \\
\text { loss }\end{array}$ & & & & & \\
\hline $\begin{array}{l}\text { Static } \\
\text { dynamic }\end{array}$ & $\begin{array}{l}158 \\
149 \\
\end{array}$ & $\begin{array}{l}159 \\
150\end{array}$ & $\begin{array}{l}154 \\
145\end{array}$ & $\begin{array}{l}145 \\
136\end{array}$ & $\begin{array}{l}\mathrm{dB} \\
\mathrm{dB}\end{array}$ \\
\hline
\end{tabular}

Tinggi antena BS (hb) adalah $60 \mathrm{~m}$ dan tinggi antena MS $(\mathrm{hm})$ ditentukan berdasarkan standar umum (mengacu pada tinggi manusia $)=1.5 \mathrm{~m}$, maka dari persamaan (1) didapat :

$$
\begin{aligned}
150= & 69.55+26.16 \log (400)-13.82 \log (60)- \\
& {[3.2\{\log (11.75(1.5))\} 2-0.97]+[44.9-} \\
& 6.55 \log (60)] \log (\mathrm{d}) \\
= & 69.55+26.16 \log (400)-13.82 \log (60) \\
& {[3.2\{\log (11.75(1.5))\} 2-4.97]+[44.9-} \\
& 6.55 \log (60)] \log (\mathrm{R}) \\
= & 69.55+26.16(2.60)-13.82(1.78)-[3.2\{1.55\}- \\
& 4.97]+[44.9-6.55(1.78)] \operatorname{logR} \\
150 & \\
150= & 69.55+68.02-24.60-0+33.24 \log \mathrm{K} \\
150= & 137.57-24.60+33.24 \operatorname{logR} \\
150= & 112.97+33.24 \log \mathrm{R} \\
\mathrm{R}= & \log -1(37.03 / 33.24) \\
= & 13 \mathrm{Km}
\end{aligned}
$$




\section{Teknik, 40 (2), 2019, 103}

Maka luas coverage per sel BS merupakan luas heksagonal dengan jari-jari $(\mathrm{r})=13 \mathrm{Km}$.

$$
\begin{aligned}
\mathrm{L} & =6\left(0.5 \mathrm{r} 2 \operatorname{Sin} 60^{\circ}\right) \\
& =439.07 \mathrm{Km} 2
\end{aligned}
$$

Jumlah BS yang dibutuhkan di kota Bandung $=($ Luas kota Bandung $):($ Luas coverage $\mathrm{BS})$ $=(167.3 \mathrm{Km} 2):(439.07 \mathrm{Km} 2)=0.38$

Artinya kota Bandung cukup dicatu hanya dengan sebuah 1 BS. Penempatan BS tidak boleh sembarangan, karena ada Peraturan daerah Kota Bandung yang mengatur. Di samping itu penempatan BS juga harus optimal. Dari dua pertimbangan itu, maka BS ditempatkan di Kantor Walikota Bandung.

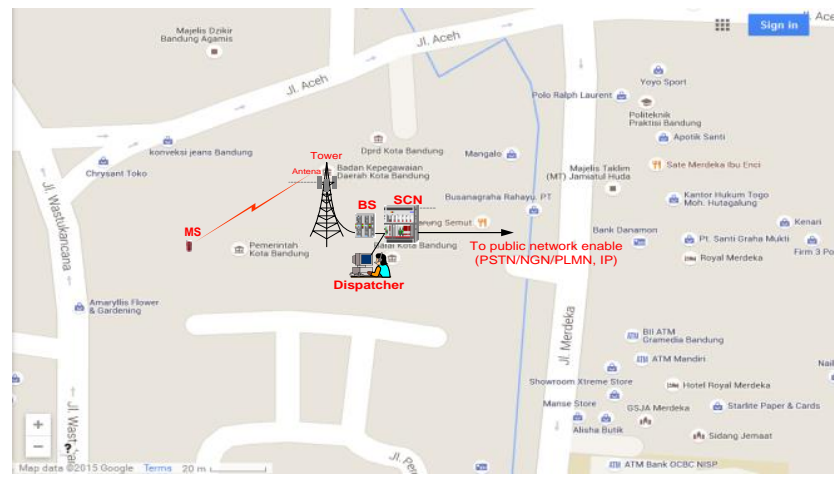

Gambar 4. Penempatan BS di kantor Walikota Bandung.

Dari Gambar 4 dapat dilihat bahwa area layanan dari GRN yang dirancang melebihi dari area Kota Bandung sampai meliputi dari kota Cimahi dan Kabupaten Bandung sebagai kota tetangga Bandung.

\section{KOTA INTI METROPOLITAN BANDUNG}

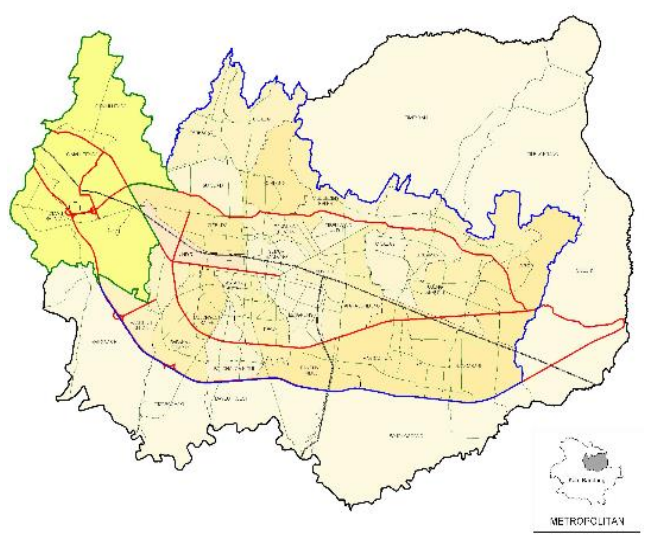

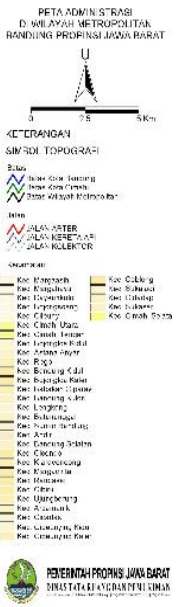

Gambar 5. Coverage Area GRN.

Jika luas coverage sel (Gambar 5) akan dipersempit sehingga mendekati luas kota Bandung, maka dapat dilakukan salah satu atau kombinasi dari tiga cara berikut, yaitu: (1) menurunkan ketinggian antena BS, (2) menurunkan PTx dan (3) menundukkan arah antena BS (down tilting). Artikel ini tidak membahas tiga hal ini dengan maksud ke depannya penerapan GRN pada instansi PPDR akan diimplementasikan di seluruh wilayah Indonesia, sehingga daerah sekitar kota Bandung seperti wilayah Kabupaten Bandung dan Kota Cimahi sebagian masih bisa terlayani.

Kajian kebutuhan kanal dan lebar pita pita frekuensi untuk kegiatan PPDR ini diskenariokan bahwa lembaga atau instansi yang menangani PPDR dibagi menjadi 7 kelompok. Ini mengacu kepada tim PPDR di kota Surabaya Jawa Timur, bahwa jumlah tiap instansi/lembaga minimal berjumlah 100 pengguna (orang) sudah termasuk ketua kelompok atau koordinator, sehingga total pengguna adalah 7 kelompok $\mathrm{x} 100$ pengguna $=700$ pengguna. . Jika diasumsikan tiap pengguna membangkitkan trafik sebesar $50 \mathrm{mE}$, maka trafik yang akan terjadi pada suatu sel (BS) adalah $700 \mathrm{x}$ $50 \mathrm{mE}=35$ Erlang. Jumlah kebutuhan ini relatif rendah, dengan pertimbangan, bahwa dalam radio trunking, kebanyakan bersifat talk group dimana sebuah kanal dipakai bersama.

Untuk ketua kelompok dan seluruh anggota kelompok panggilan darurat dikategorisasikan sebagai pengguna prioritas 1. Pengguna prioritas 1 menggunakan model trafik ErLang $\mathrm{B}$, sedangkan pengguna prioritas 2 menggunakan model Erlang C.

Dalam radio trunking ketika salah satu pengguna dalam suatu grup berbicara, maka kebutuhan kanal sebenarnya hanya satu kanal, berapapun jumlah anggota dalam group tsb. Namun dalam memberikan peluang kemungkinan keberhasilan memperoleh kanal cukup besar atau didelay dalam waktu singkat setiap saat terutama saat jam sibuk, tidak hanya memperhitungkan kemungkinan panggilan dari anggota kepada ketua kelompok, namun juga kemungkinan panggilan dari setiap anggota dari semua kelompok ke dispatcher termasuk ketua regu serta kemungkinan panggilan antar ketua regu (koordinasi) maka dalam analisis trafik adalah seluruh pengguna diperhitungkan memiliki peluang yang sama, dengan peluang tiap pengguna ratarata membangkitkan trafik sebesar 50 mili Erlang $(\mathrm{mE})$ dan peluang (probabilitas) kegagalan (tidak mendapatkan kanal) tiap pengguna sangat kecil yaitu $1 \%$ untuk pengguna prioritas 1 , dan kemungkinan didelay hingga 5 detik untuk pengguna dengan prioritas 2 , maka untuk 700 pengguna besarnya intensitas trafik (A) adalah : $700 \times 50 \mathrm{mE}=35 \mathrm{E}$. Jika dikehendaki angka kegagalan (Blocking Probability, B) maksimal 1\%, maka jumlah kanal minimal yang dibutuhkan (N) 


\section{Teknik, 40 (2), 2019, 104}

berdasarkan formula Erlang $\mathrm{B}$ yang menyatakan hubungan antara A, B, dan $\mathrm{N}$ adalah (Rappaport, 2002):

$\mathrm{B}(\mathrm{N}, \mathrm{A})=\frac{\frac{A^{N}}{\mathrm{~N} !}}{\sum_{i=0}^{N} \frac{A^{i}}{i !}}$

Adapun formula tersebut sudah ditabelkan untuk berbagai intensitas trafik A dan beberapa prosentase peluang kegagalan (GoS). Dari tabel tersebut untuk trafik sebesar 35 Erlang dengan $\mathrm{B}=1 \%$, maka kebutuhan kanal adalah 47 kanal. Demikian pula untuk panggilan prioritas 2 dengan perhitungan model Erlang $\mathrm{C}$, untuk jumlah kanal 47, jika diinginkan kemungkinan di-delay 1 detik, maka trafik yang mungkin gagal mendekati $0 \%$.

Dengan menggunakan teknologi standar TETRA dimana spasi frekuensi carrier $25 \mathrm{KHz}$ yang terdiri dari 4 Time Slot (kanal) dimana 3 kanal digunakan untuk voice/data, dan 1 kanal untuk kontrol (signaling), maka kebutuhan jumlah carrier untuk satu arah (uplink/downlink) adalah (47/3) carrier $=16$ carrier $(25$ $\mathrm{KHz}$ ), sehingga kebutuhan spektrum untuk satu arah $($ uplink/downlink $)=(16 \times 25) \mathrm{KHz}=400 \mathrm{KHz}$. Maka kebutuhan spektrum untuk kedua arah (uplink dan downlink) $=2$ x $400 \mathrm{KHz}=800 \mathrm{KHz}$. Kebutuhan spektrum total tinggal menambahkan spasi (Guard band) antara uplink dengan downlink $=800 \mathrm{KHz}+$ Guard band.

Selanjutnya adalah perencanaan arsitektur jaringan sesuai dengan standar TETRA dengan menggunakan teknologi digital berbasis circuit switch sesuai dengan Gambar 6.

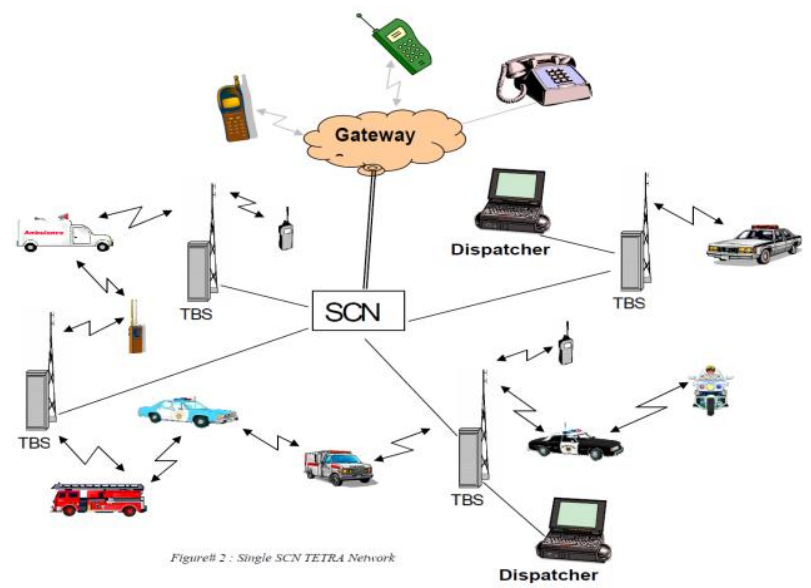

Gambar 6. Arsitektur TETRA berbasis circuit switch.

\section{Kesimpulan}

Analisis penggunaan GRN untuk integrasi sistem komunikasi PPDR sudah dilakukan. Hasil penelitian menunjukkan jumlah BS yang dibutuhkan hanya satu unit untuk melayani kota Bandung. BS dapat diletakkan di kantor Walikota Bandung. Satu unit BS dapat melayani sebagian kota Cimahi dan Kabupaten Bandung yang bertetanggaan dengan Kota Bandung. Teknologi radio yang diimpelementasikan adalah TETRA dengan frekuensi operasi $400 \mathrm{MHz}$ dan lebar pita $800 \mathrm{KHz}+$ guard band.

Untuk penelitian selanjutnya dapat dibuat analisis pemodelan komunikasi PPDR menggunakan GRN yang melayani provinsi Jawa Barat, bahkan untuk melayani seluruh Republik Indonesia.

\section{Ucapan Terima Kasih}

Terima kasih disampaikan kepada Universitas Telkom Bandung yang telah mendanai penelitian dan jurnal ini dengan skema Penelitian Dana Mandiri (PDM).

\section{Daftar Pustaka}

Aryanta, D. (2018) Analisis Penggunaan Frequency Band $400 \mathrm{MHz}$ dan $700 \mathrm{MHz}$ untuk Layanan Broadband PPDR di Indonesia. Elkomika, 6(1), $35-48$.

Azmi, R. (2013). Analisis Migrasi Radio Trunking Analog ke Radio Trunking Digital di Indonesia. Buletin Pos dan Telekomunikasi, 11(3), 247-264.

Clara, A., Astuti, R. P., Sugesti, E. S. (2016) Perencanaan terrestrial Trunked Radio (TETRA) digital pada Kereta Bandara Soekarno HattaHalim Perdana Kusuma. E-Proceeding of Engineering, 3(3), 43-63.

Dinas Komunikasi dan Informatika Kota Bandung. (2019). Portal Resmi Kota Bandung. Diakses dari www.bandung.go.id, tanggal 28 Juli 2019.

European Telecommunications Standards Institute (1997). Terrestrial Trunked Radio (TETRA), Voice plus Data $(\mathrm{V}+\mathrm{D})$, Designers' guide, Part 1: Overview, technical description and radio aspec. Diakses dari https://www.etsi.org/deliver/etsi_etr/300_399/30 001/01_60/etr_30001e01p.pdf, tanggal 28 Juli 2019.

Kunavet, K. (2014). An Overview of Digital Trunked Radio : Technlogies and Standards. The Journal of Industrial Technology, 10(2), 111-121.

Manik, C. R., Arfianto, F, Maulana, M.I. (2015). Analisis Pengalokasian Frekuensi untuk Penerapan Public Protection and Disaster Relief (PPDR) di Indonesia Khususnya Daerah Bandung. Prosiding Seminar Nasional ReTII. Diakses dari //journal.itny.ac.id/index.php/ReTII/article/view/ 329, tanggal 28 Juli 2019. 


\section{Teknik, 40 (2), 2019, 105}

Nurjihad, S., Mulyana, A., Riza, T. A. (2014) Planning TETRA Dinas Kepolisian Polrestabes Wilayah Bandung. Proyek Akhir, Universitas Telkom.

Rappaport, T. S. (2002). Wireless Communication, Principles and Practice. 2nd edition. New Jersey: Prentice-Hall
Yuniarti, D. (2014). Pemanfaatan Frekuensi Untuk Public Protection and Disaster Relief (PPDR). Buletin Pos dan Telekomunikasi, 12(1), 73-84. 